occur during the time that every sound-wave lasts, and by letting them control a crowd of electrons in an exhausted vessel or vacuum tube their intensity can be controlled by every ripple, every rustle, every shock, and every sibilant which go to constitute human speech; and the radiation emanating from the electric oscillations will then be graduated in intensity so that the waves which travel in the æther shall be strong or weak exactly as the stimulus requires.

Receive the electric waves and convey them to another empty bulb containing again a hot wire giving off electrons; the crowd of particles respond, another current is generated, carved into fluctuations of corresponding strength, and these variations of current, when employed to actuate a telephone, can accurately reproduce the tones of the distant voice.

Roughly and generally that is the plan, and the astonishing feat is carried out by various ingenious devices. I was not specially astonished by the wireless transmission of coarse signals like the dot and dash of ordinary telegraphy. It is no more difficult to send impulses across space than to guide them by wires. What Mr. Marconi has made practical as "wireless" might have come in first, and then wires might have been regarded "as an improvement, like speaking through a tube instead of shouting into the open air. Any mechanical sending key and many a mechanical relay can accomplish that, but no mechanical relay could follow the variations of quality in human voice; no agency short of the electron would be quick and docile enough; but with their aid the feat is accomplished, and the electric waves which act as the intermediary can travel a thousand miles or more before being received and once again transmuted.

One more principle I must emphasise. How can the human ear or any instrument follow vibrations of millions a second? It cannot. Only the electron can do that. But suppose that, in addition to the oscillations coming from a distant station, we set up home oscillations in a small subsidiary vacuum tube of nearly the same frequency. Let the incoming waves vibrate a million times, for instance, while our local arrangement vibrates a million plus 500. What will happen? They will "beat." They will give 500 beats a second, and that is a musical note. To that we can listen, and upon that the variations of intensity can be superposed.

This is not the first plan adopted. The first plan was the utilisation of crystals and other detectors, such as the Fleming valve, to rectify the oscillation, to check all the negative pulses and utilise all the positive, to let only one sign through. Thus we got the vacuum valve. But soon this was improved by Lee Forest into a magnifier, so that an original impulse, exceedingly weak, could be strengthened a hundred or even a thousand times by using the electrons as relays and putting a number of relays in series.

So also for transmitting, the magnifying device is available. The electric impulses from the first valve, the one directly actuated by the microphone - these need not be given to the æther; they can be used to stimulate another valve, so as to increase their intensity until the waves generated are powerful enough to be allowed to rush across the Atlantic. This they are able to do in a fraction of a second. And there, though what arrives is only a feeble residue, since they have spread far and wide by that time, yet they preserve all their peculiarities intact, every pulse of the speech is retained and can be reproduced, and by adequate magnification can be made easily audible.

Distance is no deterrent; it only enfeebles; it does not confuse and spoil, as it does with a wire embedded in the ocean. The properties of the æther are perfect, and all the fluctuations are accurately conveyed. All that we require is a magnifier to get a convenient intensity, and that the ingenuity of man has supplied. We have learnt to communicate efficiently across space void of matter. Possibilities are thus opened up the end of which no man can foresee.

\title{
Variations of Climate since the Ice Age.
}

By C. E. P. Brooks.

$\mathrm{T}^{\mathrm{H}}$ $\mathrm{E}$ nineteenth century envisaged the Ice age as a remote catastrophe, sharply separated from the changeless present. The past twenty years have reversed that view; geologists and botanists have traced considerable fluctuations of temperature and rainfall extending from the last (Würmian) glacial period into historical times, while archæologists, working backwards from the present, have met them at the dawn of history with conditions appreciably different from those of to-day. In the countries bordering on the North Atlantic at least, the facts have been laid down with security, and it is now the task of meteoro-

\footnotetext{
1 Abridged from a paper in the Quarterly Journal of the Royal Meteoroogical Society, July, 1921, pp. 173-94.
}

logists to elucidate the various distributions of pressure and winds which were associated with these changes of climate.

At the present day the great ice-sheets of Green. land and the Antarctic Continent are occupied by permanent areas of high pressure, and we may infer that the Quaternary ice-sheets of northern Europe and North America were cccupied ty similar anticyclones, with dry easterly winds on their southern borders. In Europe at least there is direct evidence of this in a belt of "fossil dunes " extending from Russia to Holland; these dunes are crescent-shaped with their convexities to the east, indicating that they were formed by easterly winds. The Atlantic must have been a 
centre of storm development then as now, but the anticyclone over northern Europe prevented these storms from taking their present northern track and forced them into the Mediterranean, where they brought increased rainfall and a "pluvial period." These meteorological conditions are indicated in Fig. I. (The illustrations are reproduced by permission of the Council of the Royal Meteorological Society.) By reference to the estimates of Penck and Bruckner in the Alps and to the "geochronological " work of Baron de Geer in Sweden, this map is considered to represent conditions prevailing until about r8,000 B.C.

The presence of the ice-sheet is attributed to elevation in Scandinavia (see Nature, vol. ro2, p. 335). With the subsidence of the land the ice

Phase.
1. The Continental Phase
2. The Maritime Phase
3. The Later Forest Pnase
4. The Peat-bog Hhase
5. The Present Phase

About 6000 B.c. elevation closed the outlet to the Baltic for the second time, converting it into the large freshwater Ancylus lake. This shutting out of the Atlantic accentuated continental conditions in Scandinavia. The winter climate was severe; at first during the formation of the Ragunda moraines the summers were not especially warm, but later they became hot and dusty. The rainfall was scanty, and the general climate resembled that of South-east Europe. Throughout this phase Scandinavia was occupied by a rich forest flora, and towards the close conditions were very favourable to

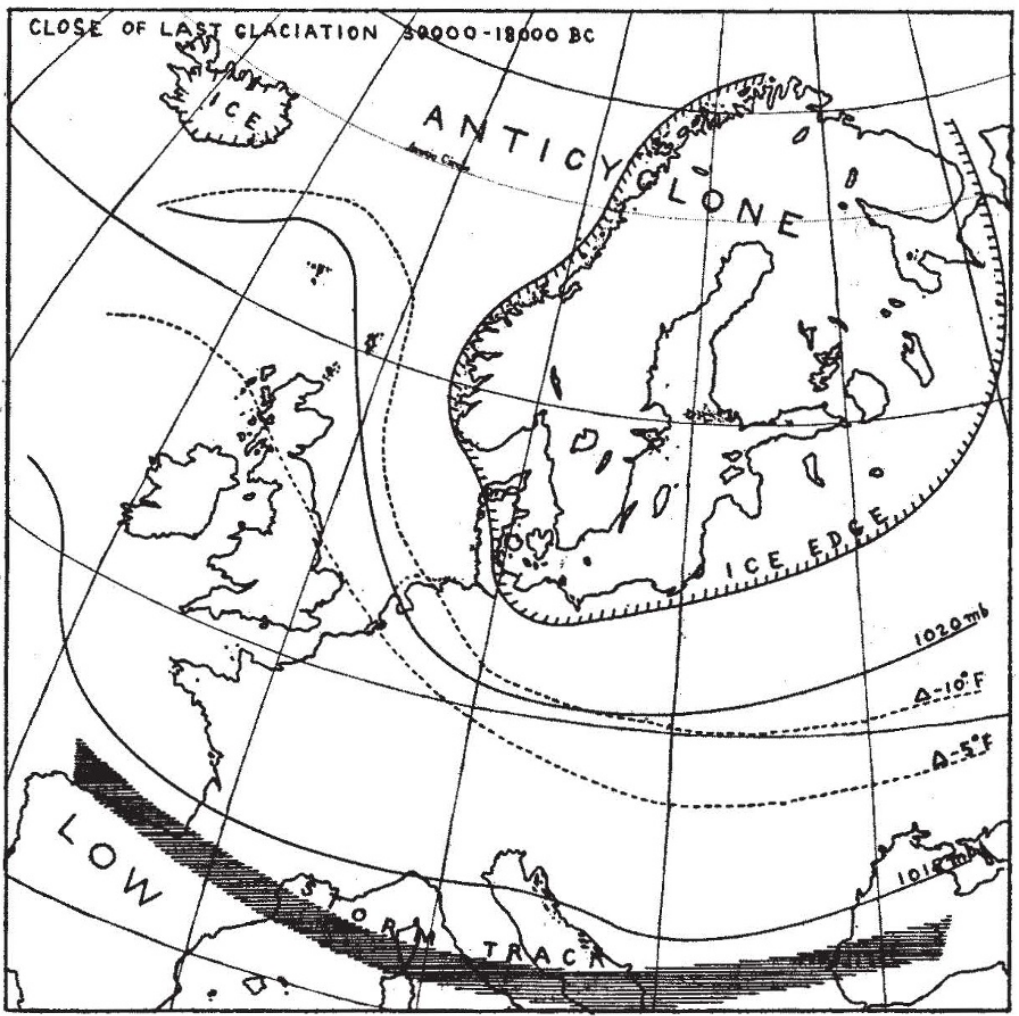

Fig. I.-Pressure and temperature distribution at the close of the last glaciation. tree-growth. The hazel extended several degrees north of its present position and to higher levels, indicating a July temperature about seven degrees higher than the present. But the ivy and yew, the limits of which depend on the winter rather than on the summer temperature, showed no such extension, indicating that the winters remained severe. The absence of storms off the north-west coast of Norway is shown by the forests, which at this period covered all the outermost islands as far as the Ingo Islands off North Cape. These islands are now barren, and their afforestation indicates a drier and less stormy climate than the present, with a decreased frequency of winds from the sea. These continental conditions, however, did not extend so far west as Ireland. As the glacial anticyclone decreased in intensity, depressions from the Atlantic began to take a more northerly course, but were held up near the British Isles and materially increased the rainfall there, forming the first peat-bogs of the western coasts. It seems

receded, slowly at first, then more rapidly, but about 8000 B.c. and again at 5000 B.c., when elevation temporarily closed the connection between the Baltic and the Atlantic, there were halts or slight readvances forming the great Scanian and Ragunda moraines. At the same time the Alpine glaciers, which throughout seem to run parallel with the Scandinavian, formed the moraines of the Gschnitz and Daun stadia.

Until 6000 B.c. the ice-sheet was still large enough to maintain a border of dry Arctic conditions on its southern edge, but the mean annual temperature of southern Sweden rose from $I 7^{\circ} \mathrm{F}$. to $35^{\circ} \mathrm{F}$. After 6000 B.C. the Ice age is regarded as over, and the subsequent climatic history can be divided into a series of "phases," as follows : probable, however, that southern and eastern England largely escaped this damp period, sharing in the dry climate of the Continent.

About 4000 B.c. submergence once more allowed the Atlantic waters to flow into the Ancylus lake through a wide strait, much broader than the present outlet, forming the Litorina sea, which was appreciably larger than the present-Baltic, and the Continental Phase gave place to a Maritime Phase, very moist and equable. Depressions now passed freely into the Baltic region, rainfall was heavy, and peat-bogs began to form over extensive areas. This favourable climate was best developed in the Baltic countries where submergence was greatest, but the whole of the North Atlantic and neighbouring parts of the Arctic shared in it to some extent,

No. 2707 , VOL. IO8] 
for raised beaches about $25 \mathrm{ft}$. above the present level with a warm fauna extended from the east of North America to Spitsbergen and the White Sea. This suggests some general factor which by altering the circulation of the North Atlantic piled up its waters in cold temperate and polar latitudes, producing a period of widespread development of warm maritime climates termed the " Climatic Optimum."

By 3000 B.C. another wave of elevation affected the southern half of the British Isles and neighbouring parts of Europe, which stood about $90 \mathrm{ft}$. above their present level. At the same time the climate became drier, and a magnificent growth of forests occurred even on the bogs of Ireland, which were extensively inhabited by Neolithic man. Many shallow lakes were more or less dried up and trees grew on their floors (Fig. 2); this is the Later Forest Phase. Tree stools in exposed situations in the west of Ireland, as well as evidence of considerable sea-borne

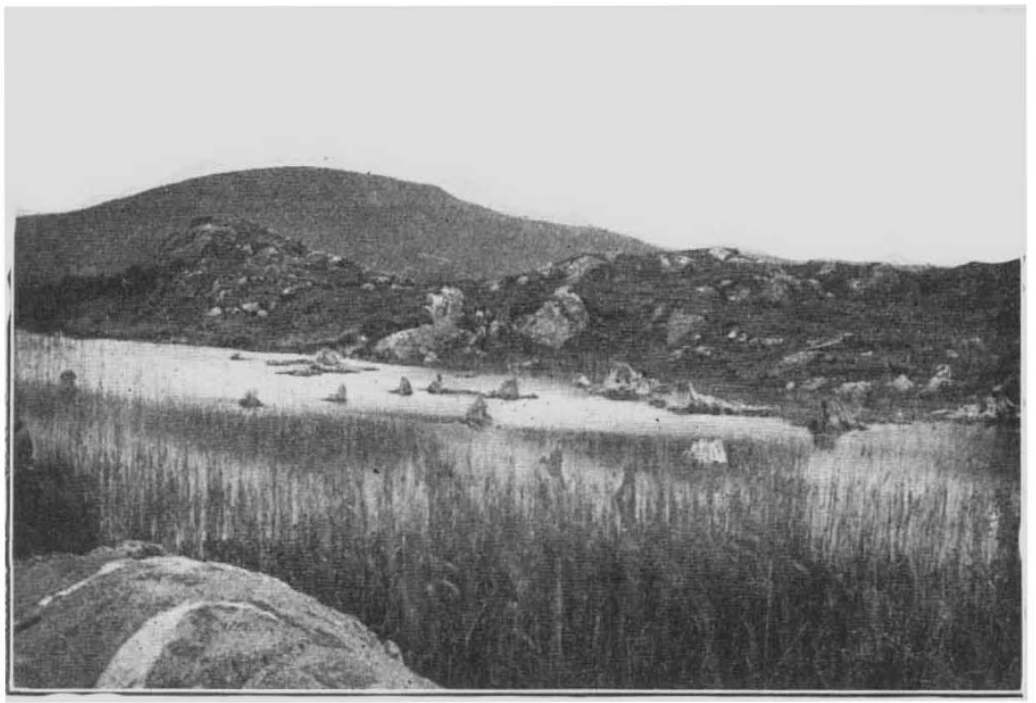

FIG 2.-Submerged tree stools in lough, Ireland.

commerce between Scandinavia and the British Isles, testify to an absence of strong winds. Conditions were anticyclonic, with possibly cold winters, but with fine, warm summers and a relatively small rainfall. Neolithic civilisation rose rapidly to its culminating point, especially in naturally moist countries like Norway and Ireland. This period, in fact, appears to coincide with the legendary Heroic age of Ireland, when the vigour of the Irish reached a level they have never since attained, an interesting confirmation of Ellsworth Huntington's theory that at present the high humidity of that country lowers the energy of its inhabitants.

By 1600 B.c. the land had again sunk to its present level, or possibly a few feet. lower. The tavourable anticyclonic conditions gave place to great storminess with relatively heavy rainfall, and there set in a period of intense peat formation in Ireland, Scotland, No. 2707 , VOL. IO8]
Scandinavia, and North Germany. This growth went on even over high ground which had not previously been covered by peat, for in Ireland tumuli of the Bronze age are found resting on rock and covered by several feet of bog. As the Bronze age gave place to the Early Iron age the climate of North-west Europe became very unfavourable, and the submergence of the early civilisation is described in Norse sagas and Germanic myths - the "Twilight of the Gods," when frost and snow ruled the world for generations (about 650 to 400 B.c.). Peat formation went on even over the Frisian dunes.

This wet period, whatever its cause, was widespread, as is shown in Huntington's curves of tree-growth in California and climate in western Asia; the same author also believes that the Mediterranean lands had a heavier rainfall from about 500 B.C. to 200 A.D., and the quietude of central Asia at this time suggests similar conditions there. It seems that the phase was marked by a general increase of the storminess and rainfall of the temperate regions of the northern hemisphere at least, with a maximum between Ireland and North Germany, indicating probably that the Baltic again became the favourite track of depressions from the Atlantic. The Peat-bog Phase passed into the Present Phase fairly abruptly about 300 A.D.

An interesting astronomical theory put forward a few years ago by $\mathrm{O}$. Pettersson provides a possible explanation of the stormy climate of the Peat-bog Phase, which reached a maximum about 400 B.c. Without going into details, his theory is that storminess in the North Atlantic depends on the juxtaposition of masses of warm and cold water and on the presence of much ice; this is favoured by increased strength of the tides. The "tide-generating force" passes through a series of cyclic fluctuations, and according to his calculations reached maxima about 3500 B.C., 2 100 B.C., $35^{\circ}$ B.C., and r 434 A.D. That of 2500 B.C. comes into, and may have contributed to, the Maritime Phase; that of 2 Ioo B.c. falls near the middle of the Later Forest Phase, and has left no trace; but that of $35^{\circ}$ B.C. coincides accurately with the period of maximum storminess of the Peat-bog Phase. The stormy period round about I 400 A.D. is well known, and has been attributed by other authors to an absolute maximum of sunspots. The corresponding minima were in 2800 B.C., 1200 B.C., and 530 A.D., but of the first of these there is no trace. The second falls in the beginning of the Peat-bog Phase, but there is evidence of seaborne traffic between Scandinavia and Ireland about rooo B.c., suggesting an absence of stormi- 
ness. The last minimum, in 530 A.D., was a time of favourable conditions and a revival of civilisation in Scandinavia and Ireland, of little ice and good weather in the neighbouring seas, and of drought in Asia.

Looking back over the whole period since the ice-sheets dwindled to inconsiderable dimensions, we find that there have been considerable variations in the climate of North-west Europe on either side of present conditions, which have been reflected in the ups and downs of civilisation in these regions. The earlier and greater changes are easily explicable at first by the gradual with- drawal of the ice, and then by appreciable changes in the land and sea distribution, but the more recent variations, of smaller magnitude and duration, pass insensibly into the slow fluctuations of the past thousand years, and for these some other cause must be adduced, e.g., Pettersson's, possibly connected with the sun. Such a cause has probably always been in operation, but has been masked by the greater changes of geological time, so that its operation is traceable only in favourable circumstances, or in the magnified perspective of the last thirty centuries.

\section{Obituary.}

HeNRY WOODWARD.

FULL of years and honours, Dr. Henry Woodward, late keeper of geology in the British Museum, died on September 6 at Bushey, Herts. He retained his faculties almost until the end, and continued to follow with interest the progress of the science to which he had devoted his life.

Henry Woodward was born at Norwich on November 24, 1832 , the youngest son of Samuel Woodward, the well-known geologist and antiquary. His father died while he was still a child, and his education at the Norwich Grammar School ended at the age of fourteen, when he went to reside with his eldest brother, S. P. Woodward, who was then professor of natural history in the Royal Āgricultural College, Cirencester. Here he pursued studies in natural science, to which he had a decided inclination, and on his brother's removal to London in 1848 as assistant in the British Museum, Henry accompanied him in the hope of obtaining some congenial employment. In $185^{\circ}$, however, he was compelled to return to Norwich and accept a clerkship in Gurney's Bank, where he remained for seven years and devoted himself to natural history only in his scanty leisure. At last, in $185^{8}$, he realised his ambition and became assistant in the geological department of the British Museum, where he soon took full advantage of his opportunities for scientific research, and began to make numerous contributions to palæontology. In 1880 he succeeded Mr. G. R. Waterhouse as keeper, and held this office until his retirement from the museum in. I90 I

Dr. Woodward's interests were always very wide, and his first publication was a small pamphlet in . 1860 on "The Prize Microscopes of the Society of Arts, with Plain Directions for Working with Them." About the same time he began to write semi-popular articles on various new fossils received by the British Museum, and made several valuable contributions to the Intellectual Observer, the Popular Science Review, and other journals. Among these may be specially mentioned his general account of Archæopteryx in 1862 . He continued to prepare notes on new features exhibited by fossils of all kinds added to the museum, and among the earliest was his description of the skull of the mammoth found at Ilford, showing for the first time the true inward curvature of the tusks. He was especially interested in the mammalian remains discovered by Sir Antonio Brady in the Pleistocene deposits at Ilford, and he wrote an introduction to William Davies's catalogue of the collection published in I874. He also devoted much attention to the later mammalian remains found during the excavation of reservoirs in the valley of the Lea, and he contributed an account of the ancient fauna of Essex to the Proceedings of the Essex Field Club. One of his later papers of the same series contained a description and discussion of a nearly complete skeleton of the extinct Sirenian Rhytina from Behring Straits, which was published by the Geological Society in 1885 .

From the beginning, however, Dr. Woodward made a very special study of the Crustacea, and his chief contributions to science are detailed descriptions and comparisons of extinct representatives of this class. In 1863 he published his first paper on a Macruran from the Lias of Lyme Regis in the Quarterly Journal of the Geological Society. From 1865 onwards he prepared several reports, on British Fossil Crustacea for the British Association. Between 1866 and 1878 he published his well-known monograph of the Merostomata under the auspices of the Palæontographical Society. In 1877 he contributed to the British Museum catalogues a list of the British Fossil Crustacea. In ${ }^{2} 88_{3}-84$ he wrote again for the Palæontographical Society a monograph of British Carboniferous Trilobites, and afterwards joined Prof. T. Rupert Jones in a monograph of the British Palæozoic Phyllopoda for the same society. So long ago as $\mathrm{r}_{86}$ he co-operated with Mr. J. W. Salter in a chart of the genera of Fossil Crustacea, and in 1877 he wrote the article on Crustacea for the ninth edition of the Encyclopædia Britannica. He also made a special study of many other arthropoda, and published several papers on insects, arachnids, and myriapods from Carboniferous formations.

Dr. Woodward's influence on the progress of geology and palæontology was by no means confined to his writings. In 1864 he joined Prof. NO. 2707 , VOL. IO8] 